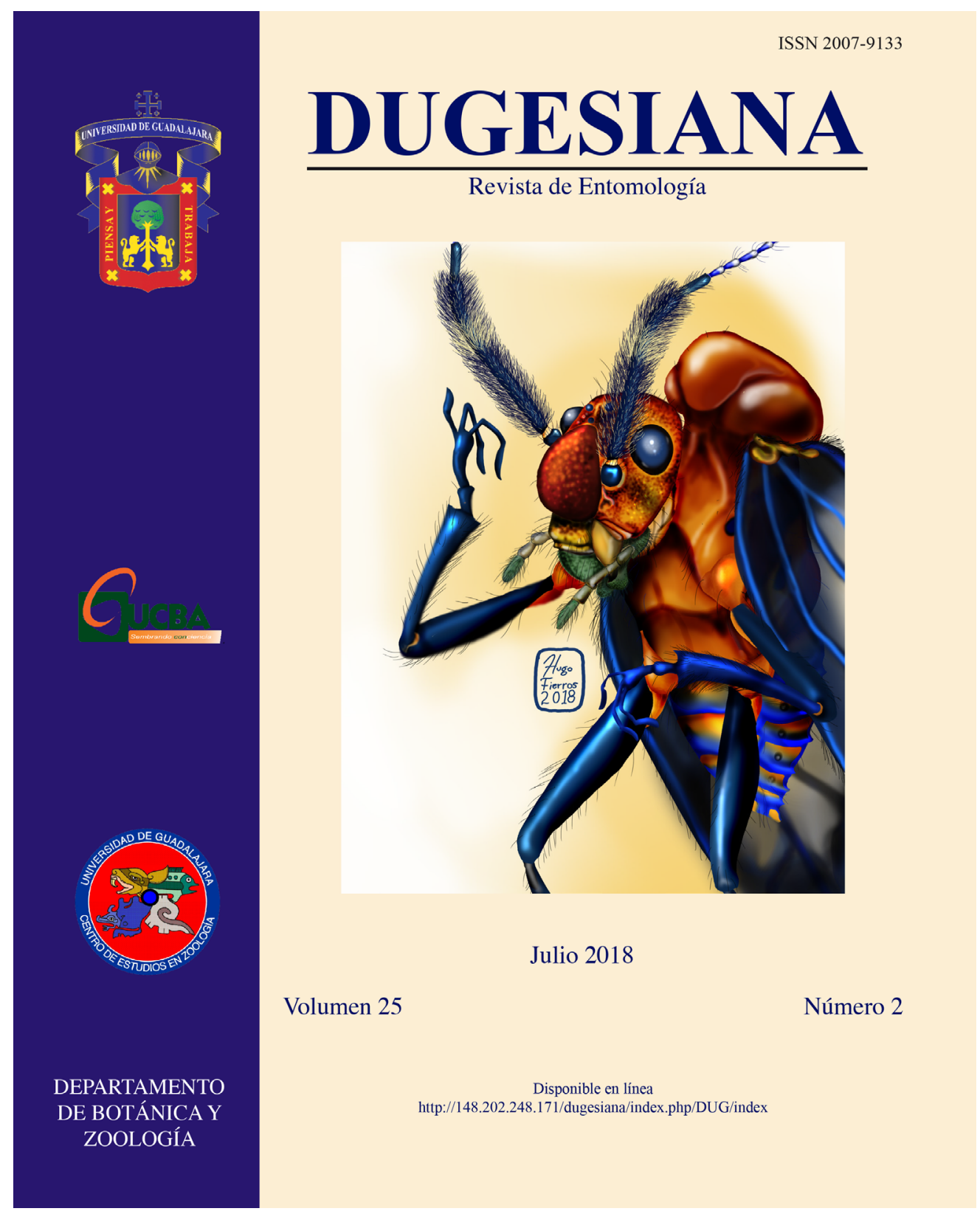

Dugesiana, Año 25, No. 2, julio 2018-diciembre 2018 (segundo semestre de 2018), es una publicación semestral, editada por la Universidad de Guadalajara, a través del Centro de Estudios en Zoología, por el Centro Universitario de Ciencias Biológicas y Agropecuarias. Camino Ramón Padilla Sánchez \# 2100, Nextipac, Zapopan, Jalisco, Tel. 37771150 ext. 33218, http://148.202.248.171/dugesiana/index.php/DUG/index, glenusmx@gmail.com. Editor responsable: José Luis Navarrete Heredia. Reserva de Derechos al Uso Exclusivo 04-2009-062310115100203, ISSN: 2007-9133, otorgados por el Instituto Nacional del Derecho de Autor. Responsable de la última actualización de este número: José Luis Navarrete Heredia, Editor y Ana Laura González-Hernández, Asistente Editorial. Fecha de la última modificación 25 de julio 2018, con un tiraje de un ejemplar.

Las opiniones expresadas por los autores no necesariamente reflejan la postura del editor de la publicación.

Queda estrictamente prohibida la reproducción total o parcial de los contenidos e imágenes de la publicación sin previa autorización de la Universidad de Guadalajara. 


\title{
A new Mexican Scapheremaeus (Acari: Oribatida: Cymbaeremaeidae) from the tropical rain forest of Los Tuxtlas, Veracruz
}

\section{Una nueva Scapheremaeus mexicana (Acari: Oribatida: Cymbaeremaeidae) de la selva tropical lluviosa de Los Tuxtlas, Veracruz}

\author{
José G. Palacios-Vargas* and Jair Páez \\ Laboratorio de Ecología y Sistemática de Microartrópodos, Departamento de Ecología y Recursos Naturales, \\ Facultad de Ciencias, Universidad Nacional Autónoma de México. 04510, Ciudad de México, México.
}

\begin{abstract}
Scapheremaeus dirzoius sp. nov. lives on the canopy of trees of Astrocaryum mexicanum Liebm. ex Mart (Arecaceae) and Guarea glabra Kunth (Meliaceae) in the tropical rainforest of Los Tuxtlas, Veracruz, it is similar to S. flamiferus Palacios-Vargas and Ríos, 1998, which lives on epiphytic Tillandsia (Bromeliaceae) from Nicaragua. They differ in the cuticular ornamentation, and the notogastral and ventral chaetotaxy, the new species has only 9 pairs of dorsal setae and 2 pairs of adanal setae versus 10 and 3 pairs in the Nicaraguan species.
\end{abstract}

Keywords: morphology, taxonomy, Scapheremaeus, canopy.

\section{RESUMEN}

Scapheremaeus dirzoius sp. nov. vive en la canopia de árboles de Astrocaryum mexicanum Liebm. ex Mart (Arecaceae) y Guarea glabra Kunth (Meliaceae) de la selva tropical lluviosa de Los Tuxtlas, Veracruz, es similar a S. flamiferus Palacios-Vargas y Ríos, 1998, misma que vive en Tillandsia (Bromeliaceae) epífitas de Nicaragua. Difieren en la ornamentación cuticular y la quetotaxia notogástrica y ventral, la nueva especie sólo tiene 9 pares de sedas dorsales y 2 pares adanales, contra 10 y 3 pares en la especie nicaragüense.

Palabras clave: morfología, taxonomía, Scapheremaeus, canopia.

The tropical rainforest of Los Tuxtlas, Veracruz has a great diversity of trees which have an important canopy as Ficus yoponensis Desv. (Moraceae), F. tecolutensis (Liebm.) Miq. (Moraceae), Ceiba pentandra (L.) Gaertn. (Malvaceae), Astrocaryum mexicanum Liebm. ex Mart (Arecaceae), Chamaedorea tepejilote Liebm. (Arecaceae) and Guarea glabra Kunth (Meliaceae) (Vázquez et al. 2010). The canopy is relevant in jungles and forests, because it promotes the dynamic and development of the fauna communities. Few contributions on microarthropods living in the canopy have been done in Mexico as those of the tropical dry forest of Chamela (Palacios-Vargas et al. 1999), using natural photodegradable piretrines for the study of arthropods. In recent studies of the canopy of tropical rain forest of Los Tuxtlas, Veracruz Villagomez et al. (2017) and Palacios-Vargas and Mejía (2017) have reported that most abundant arthropods are the Oribatid mites and springtails.

Among the Oribatid mites the family Cymbaeremaeidae Sellnick, 1928, has one peculiar genus, Scapheremaeus Berlese, 1910, which is the most diverse and with a cosmopolitan distribution; 114 species have been described (Subías 2018), and they have a remarkable affinity to epiphytic habitats, such as moss and lichens (Ríos and Palacios-Vargas 1998) usually from the canopies of jungles and forest. They are found in many different habitats, as in semi-desert and in dry moss and maritime lichens (Colloff 2009). But they are also found on leaves of rainforest trees, corticolous lichens and moss, and can be obtained by insecticide fogging of the forest canopy, in forest litter and even in temporary pools. Several species are associated with epiphytic plants, especially bromeliads, from wet tropical and sub-tropical forest.

Colloff (2009) made the most important revision of the genus, based in the morphology and isolated 13 groups. Besides, there are two categories depending on the circumdorsal scissure, A) species that have a complete circumdorsal scissure with plicate microsculpture on the circumnotogastral plate and strongly contrasting microsculpture (foveolae, ridges or tubercles) on the centrodorsal plate (plicate species-groups), and B) species with the circumdorsal scissure complete, incomplete or absent but with little or no contrast in microsculpture between the central and lateral regions: typically both regions foveolate or reticulate (nonplicate species-groups). Studies of Mexican Scapheremaeus have been done from different types of vegetation and 17 species were described (Palacios-Vargas et al. 1998, Palacios-Vargas and Ríos 1998, Ríos 1996, Ríos and Palacios-Vargas 1998).

Five species of Scapheremaeus have been recorded 
from the canopy of two trees in the tropical rain forest of Los Tuxtlas, Astrocaryum mexicanum and Guarea glabra (Villagomez, et al. 2017), one of them very abundant, but others are very scare (Ríos 1996); three species S. baloghius, S. hectorperezius and S. alvarezius Ríos y Palacios-Vargas, 1998 were formally described some time ago, but at least two others remain undescribed. The less abundant new species is described here.

\section{Diagnosis. Modified after Colloff, 2009}

Brachypyline oribatid mites, from family Cymbaeremaeidae with ornamented notogaster, an anterior lenticulus and a complete or incomplete circumdorsal scissure, sometimes reduced. Sensillus typically darkly pigmented, globose, club-shaped apically, smooth, or barbate, often moruliform. Genital and anal apertures not closely adjacent. Notched tutorium absent, but a lateral carina may be present. Lamellar setae setiform, bacilliform slightly or dark pigmented with or without club-shaped form due to cerotegument; lamellar setae associated with costulae. Interlamellar setae setiform or peg-like, represented only by alveoli or absent. Bothridium well developed, not obscured by notogaster in dorsal view.

Exobothridial setae present or absent. Dorsosejugal suture continuous, convex; notogaster with complete or incomplete circumdorsal scissure, separating centrodorsal plate from dorsal circumnotogastral plate; sometimes reduced, visible only by difference in lateral and centrodorsal microsculpture; rarely absent. Usually 3 pairs of lyrifissures concentrated posteriorly on circumnotogastral rim, central part of notogaster with microsculpture of tubercles and/ or ridges or alveoli, partly cerotegumental in origin. With typically 10,14 or 15 pairs of setiform notogastral setae, more rarely $7,9,12$ or 13 pairs. With or without humeral spines extending ventrally. Epimeral setal formula 3-1-22 or rarely 3-1-3-3 (2-1-2-1, 3-1-1-2). Junction of epimere IV and ventral plate without enantiophyses; caudal margin of venter U-shaped, not V-shaped; genital and anal plates separated by distance similar length of genital aperture; 2 , 4, 6 or 7 pairs of genital setae; one pair of aggenital setae; one or two pairs of anal setae situated on median edge of plates or some distance from median edge; 3 or 2 pairs of adanal setae. With triangular pre-anal sclerite. Legs monodactylous or tridactylous.

Type species: S. patella (Berlese, 1886)

\section{MATERIAL AND METHODS}

Specimens were collected by means of fogging of the canopy with natural piretrines in two trees: Astrocaryum mexicanum and Guarea glabra. To catch the specimens, white plastic sheets of $2 \times 2 \mathrm{~m}$ where put under each tree (Palacios-Vargas and Mejia 2017). Specimens were preserved in $70 \%$ alcohol in transparent jars. Under the stereoscopic microscope specimens were sorted. Those of Scapheremaeus were put in lactic acid at $45^{\circ} \mathrm{C}$ until they were cleared and then mounted under cover and slides for study and illustration in the contrast phase microscopy. Then they were dried up in the oven for a week.

\section{RESULTS}

Scapheremaeus dirzoius sp. nov. (Figs.1-10)

http://zoobank.org/F7430A4C-4E41-4C69-B66B55AC99A55DA6

Description: Dimensions: Total length: (mean and range; $\mathrm{n}=6): 340 \mu \mathrm{m}(232-372 \mu \mathrm{m})$. Width: $190 \mu \mathrm{m}$; (180-202).

Integument. Cerotegument irregularly distributed. All surfaces of body with ornate microsculpture.

Prodorsum. Tuberculate laterally, with rugose pattern of poorly defined ridges medially between costulae. Rostrum rounded, rostral setae (ro) smooth, pointed, ca. 11 $\boldsymbol{\mu} \mathrm{m}$ long; lamellar setae (le; ca. $5 \boldsymbol{\mu m}$ long) with acuminate tips, on small tubercles, connected by translamella (Fig. 1). Costulae well developed, more-or-less parallel, extending posteriorly close to bothridia. Interlamellar setae (in) absent. Sensillus club-shaped, darkly-pigmented, smooth, head ca. $19 \mu \mathrm{m}$ broad, apex not extending well beyond prodorsal margin; stalk about $25 \mu \mathrm{m}$ long (Fig. 1). Chelicerae with dorsal seta $c h a$ (Fig. 2). Mentum smooth with setae $h, m, a$ and rutelae well developed (Fig. 3). Setal formula of palp: 1-1-3-9(1) not illustrated.

Notogaster. Length $(\mathrm{n}=6): 247 \mu \mathrm{m}$, width $(\mathrm{n}=6)$ : $190 \mu \mathrm{m}$. Circumdorsal scissure entire, with diagonal extensions into humeral region (Fig. 4). Lenticulus present (ca. 41 long, 38 broad) flanked by circular protuberances. Centrodorsal region $185 \mu \mathrm{m}$ long, $111 \mu \mathrm{m}$ broad; with microsculpture consisting of regular arranged foveolae, and some external spherical tubercles. Microsculpture of region lateral of circumdorsal scissure consisting of parallel ridges and troughs. Nine pairs of smooth, short (8-14 $\mu \mathrm{m}$ long) spiniform notogastral setae borne on short tubercles; the setae present are $c_{2}, l a, l m, l p, h_{2} \mathrm{y} h_{3}, p_{1}, p_{2}$ and $p_{3 ;} l m$ and $l p$ positioned on centrodorsal region (Fig. 4). Posterior region indented very slightly. Lyrifissurae $i h$, ips and ip arranged radially on posterior half of laterodorsal region, lyrifissurae im arranged centrodoral between setae $l m$ and $l p$.

Lateral aspect. Prodorsal microsculpture composed of round, oval and elongate tubercles arranged in linear patterns. Costulae projecting markedly above surface of prodorsum; tubercle of lamellar seta free of prodorsal surface. Carina an angular ridge ventral of lamella; cusp or free projection absent. Pedotectum I auriculate, covering acetabulum I; pedoctectum II narrow, bone like, midway between acetabula II and III.

Ventral region. (Fig. 5). Epimeral setal formula 3-1$2-2$; six pairs of genital setae, $g_{1}$ offset laterally from $g_{2}$ and much longer; ovipositor normal for the group with 4 setae on each vesicle (Fig. 6) one pair of aggenital setae, two pairs of anal and two pairs of adanal setae. Ventral microsculpture consisting of foveolae. Lyrifissurae iad in para-anal position. 
Legs. (Figs. 7-10). Setal formula: leg I: 1-4-2(1)-4(1)12(1); leg II: 1-4-2(1)-3(1)-13(1); leg III: 1-2-1(1)-2(1)-11; legs IV: 1-2-1(1)-2(1)-11. Tarsi I and II have a basal cuticle scale never seen in other members of the genus (Figs. 7 and 8 ). Lengths of leg segments in $\mu \mathrm{m}$ : legs I: femora $=$ 66 , genua $=22$, tibiae $=50$, tarsi $=31$; legs II: femora $=$ 61, genua $=19$, tibiae $=35$, tarsi $=36$; legs III: femora $=$ 42 , genua $=18$, tibiae $=41$, tarsi $=31$; legs IV: femora $=$ 55 , genua $=28$, tibiae $=40, \operatorname{tarsi}=35$. Femora I-IV with tuberculate microsculpture on antiaxial surface and series of parallel ridges on paraxial surface; circular porose areas (p. a.) present on paraxial surfaces. Claws monodactylous.

Variation: One paratype with setae " $d p$ " asymmetrically duplicated on right side. There is a variation in the number of anal and adanal setae, regular number is two pairs of each, but we have observed $2+1$ anal setae (three times) and $1+2$ adanal setae (two times).

Type material: Holotype female and seven paratypes females mounted on slide. Holotype and paratypes will be kept at author's institution.

Type locality: MEXICO: Veracruz: Tropical Biological Station of Los Tuxtlas, two paratypes from Guarea glabra and six from Astrocarium mexicanum, 8-X-2016, J. G. Palacios-Vargas col. by fogging.

Etymology: This species is named after Dr. Rodolfo Dirzo Minjarez (Institute of Ecology, UNAM) dedicated for many years to the study of the tropical rainforest of Los Tuxtlas and its protection. The epithet is a noun in the genitive case according to Art. 31.1.2. of the international zoological nomenclature code but with the appropriate latin gender ending (-ius masculine).

\section{DISCUSSION}

Scapheremaeus dirzoius $\mathbf{s p . ~ n o v . ~ b e l o n g s ~ t o ~ t h e ~ p l i c a t e ~}$ species-group of Colloff (2009) because it has a complete circumdorsal scissure with plicate microsculpture on the circumnotogastral plate, strongly contrasting with the microsculpture on the centrodorsal plate (foveolate). It also belongs to the "Carinatus" group, with a complete circumdorsal scissure and the prodorsum usually with welldeveloped lateral carinae.

Scapheremaeus dirzoius sp. nov. can be distinguished from other members of the genus by the following combination of characters: microsculpture of notogaster very regular, the scissure with two lines of spherical tubercles, completely different form other species; only nine pairs of notogastral setae and only two pairs of adanal setae (most species have 3 pairs). It looks similar in appearance to $S$. flamiferus Palacios-Vargas and Ríos 1998, but they differ in the cerotegument, cuticular ornamentation, notogastral and ventral chaetotaxy; most evident is that $S$. dirzoius sp. nov. has only 9 pairs of notogastral setae and 2 pairs of adanal setae versus 10 and 3 pairs in the Nicaraguan species. $S$. flamiferus is $414 \mu \mathrm{m}$ long and $225 \mu \mathrm{m}$ width (versus 340 $\mu \mathrm{m}$ long and $190 \mu \mathrm{m}$ in the new species).

The new species is also similar to S. palustris, Sellnick,
1924 which have been cited from several places in Europe and Soviet Union. After the redescription of material from Hungary made by Mahunka (1987), the European species have 10 pairs of notogastral setae and the epimeral formula is 3-1-2-2 and the anogenital formula is 6-1-2-3. S. dirzoius sp. nov. has only 9 pairs of notogastral setae and the anogenital formula is $6-1-2-2$. Both species share the legs monodactylous and the general aspect of dorsal shape. The Hungarian specimens are $476 \mu \mathrm{m}$ length and $279 \mu \mathrm{m}$ width, and the new Mexican is $340 \mu \mathrm{m}$ long and $190 \mu \mathrm{m}$ width.

Colloff (2009) thinks that notogastral setae $h$ series are highly conserved and those of the $p$ series may be significantly reduced or absent and accompanied by the loss of adanal setae. However, S. palaciosi Ríos, 1996 has eight pairs of notogastral setae ( $p_{2}$ and $p_{3}$ are missing) but possesses a full complement of adanal setae. The case of $S$. dirzoius sp. nov. is very different, as series $\mathrm{p}$ is complete and the lacking pair of seta is $h_{l}$, and the pair of adanal seta lacking is $a d_{3}$.

\section{ACKNOWLEGMENTS}

This article is part of the project PAPIIT (UNAM) IN214816: "Ecología de Microartrópodos de la selva de Los Tuxtlas, Veracruz" The principal of the Biological Station of Los Tuxtlas, Dr. Rosamond Coates gave facilities for this research. Dr. Ignacio Castellanos (UAEH) allowed us to use his Dyna Fog machine. Students from the Sciences Faculty, UNAM, participated in the field work: Adrián Gómez, Fernando Villagomez, Jesús Cruz, Jair Páez and Ariel Quintero. Ricardo Iglesias and Fernando Villagomez gave criticism and important suggestions.

\section{LITERATURE CITED}

Colloff, M. J. 2009. Comparative morphology and speciesgroups of the oribatid mite genus Scapheremaeus (Acari: Oribatida: Cymbaeremaeidae), with new species from South Australia. Zootaxa, 2213: 1-46.

Mahunka, S. 1987. The fauna of the Kiskunság National Park. Akadémiai Kiadó, Budapest. 2: 374-376.

Palacios-Vargas, J. G. 2017. ¿Cómo colectar microartrópodos del dosel? El caso de los colémbolos y ácaros de la selva de los Tuxtlas, Veracruz. Memorias del XIX simposio de Zoología. CUCBA, U. de G. 22-26.

Palacios-Vargas and R. Mejía. 2017. Artrópodos de la canopia en la selva tropical húmeda de los Tuxtlas, Veracruz con énfasis en Collembola. Entomología Mexicana, 4: 90-95.

Palacios-Vargas, J.G. and G. Ríos. 1998. A new Scapheremaeus (Oribatei: Cymbaeremaeidae) from Central America. Revista Nicaragüense de Entomologia, 44: 29-35.

Palacios-Vargas, J. G., G. Castaño-Meneses and A. Pescador Rubio. 1999. Phenology of canopy arthropods of a tropical deciduous forest in Western Mexico. Pan-Pacific Entomologist, 75(4): 200-211. 
Palacios-Vargas, J.G., G. Ríos, and M. Vázquez. 1998. A new Mexican Scapheremaeus (Oribatei: Cymbaeremaeidae) from tropical forests. Acarologia, 39: 383-388.

Ríos, G. 1996. A peculiar new Scapheremaeus species from Mexico (Acari: Oribatida). Folia Entomologica Hungarica, 62: 237-241.

Ríos, G. and J.G, Palacios-Vargas.1998. Especies nuevas de Scapheremaeus (Acari: Oribatei: Cymbaeremaeidae) de México. Anales del Instituto de Biología. Universidad Nacional Autónoma de México, serie Zoología, 69(2): 181-215.

Recibido: 3 de mayo 2018

Aceptado: 7 de junio 2018
Subías, L.S. 2018. Listado sistemático, sinonímico y biogeográfico de los ácaros oribátidos (Acariformes, Oribatida) del mundo (Excepto fósiles). Graellsia. 60 (número extraordinario): 3-305.

Vázquez, T. M., S. Armenta, M., J. Campos, J. and C. I. Carvajal, H. (Eds). 2010. Árboles de la región de Los Tuxtlas. Comisión Organizadora del Estado de Veracruz. Library Congress. México.

Villagomez, F., R. Iglesias, and J.G. Palacios-Vargas. 2017. Los ácaros oribátidos (Acari: Oribatei) de los estratos edáficos y arbóreos de la selva alta perennifolia de los Tuxtlas, Veracruz. Entomología mexicana, 4: 28-34.

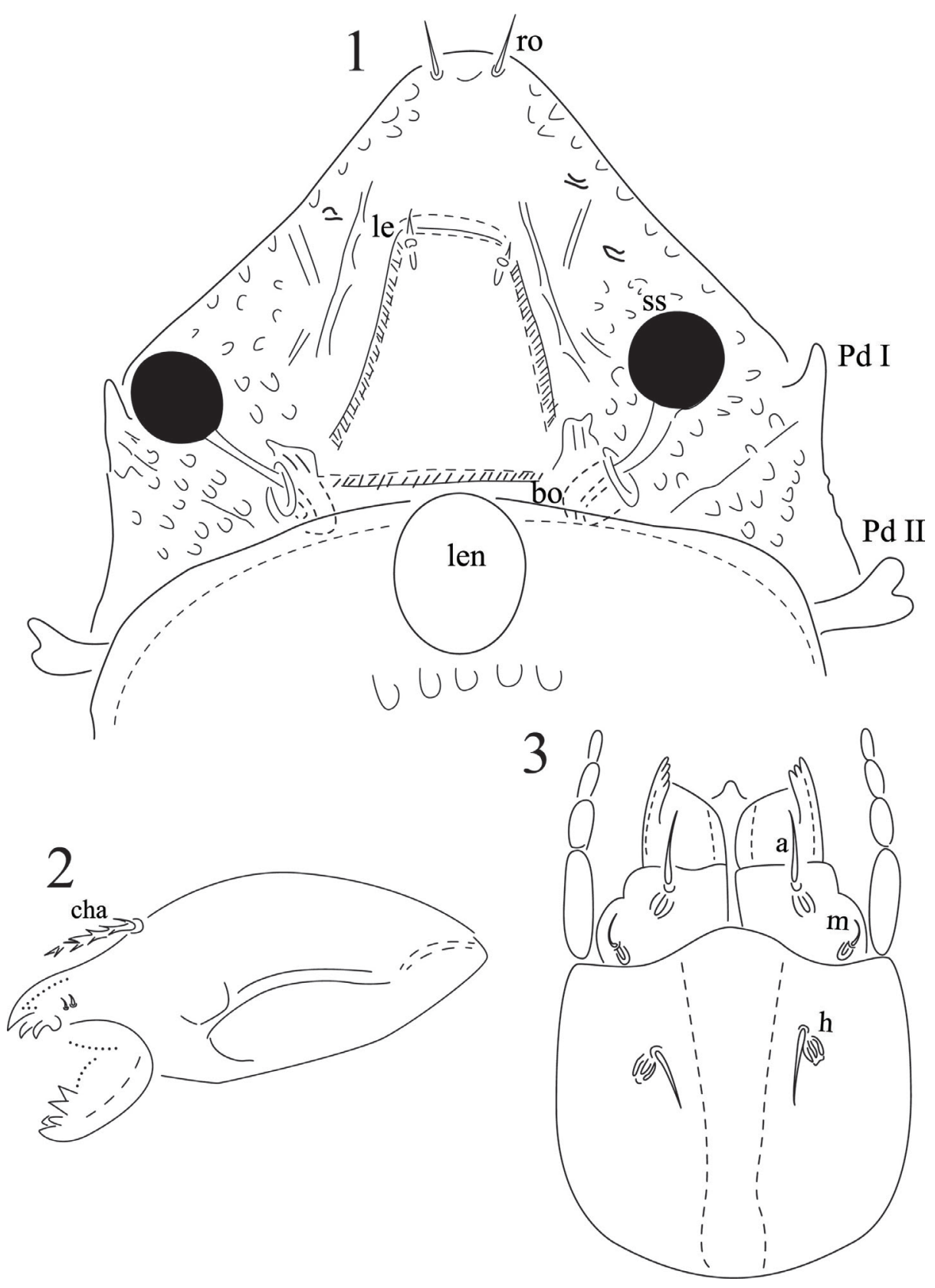

Figures 1-3. Scapheremaeus dirzoius sp. nov. 1, prodorsum ; 2, chelicera; 3, subcapitulum. 


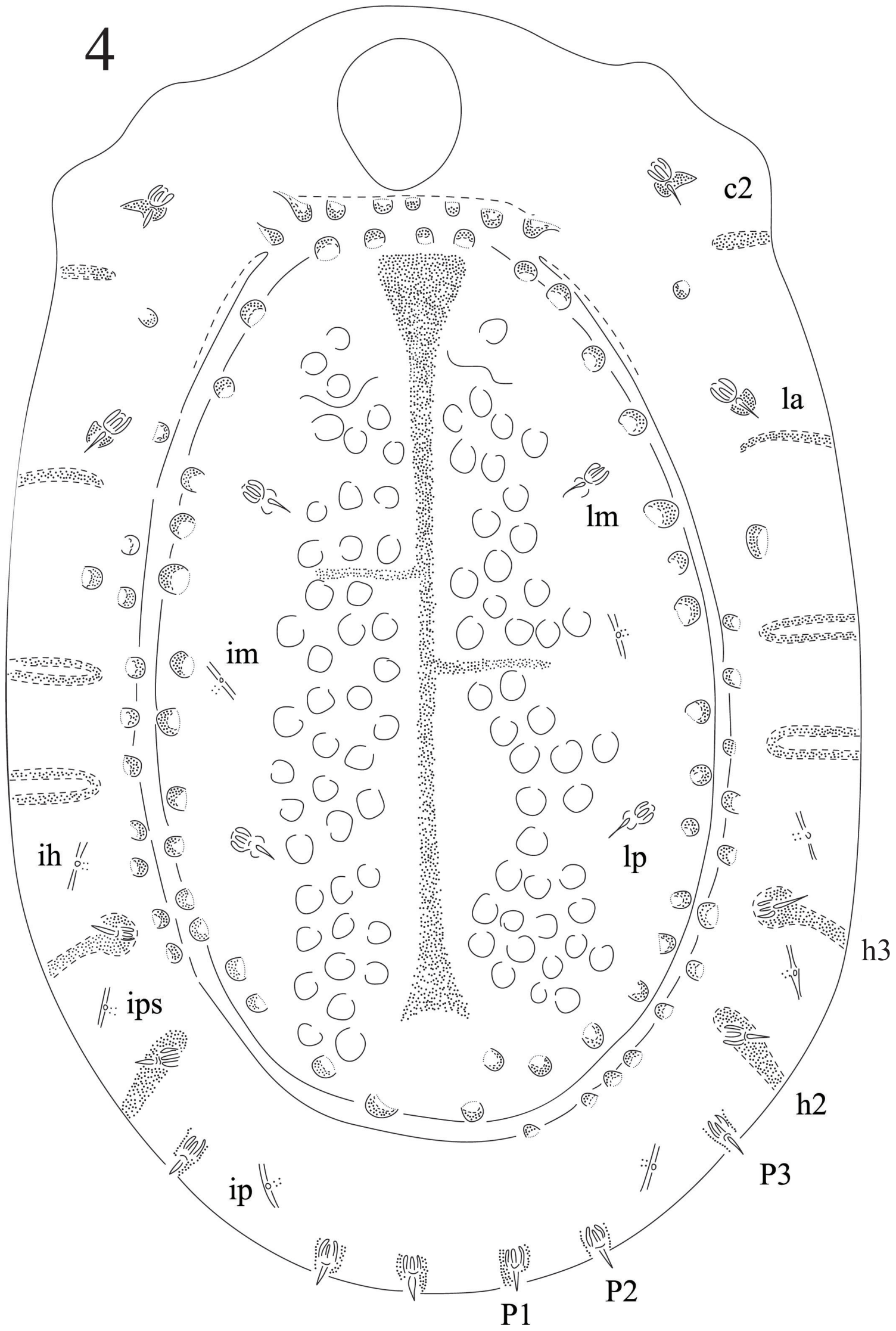

Figure 4. Scapheremaeus dirzoius sp. nov., notogaster chaetotaxy and ornamentation. 


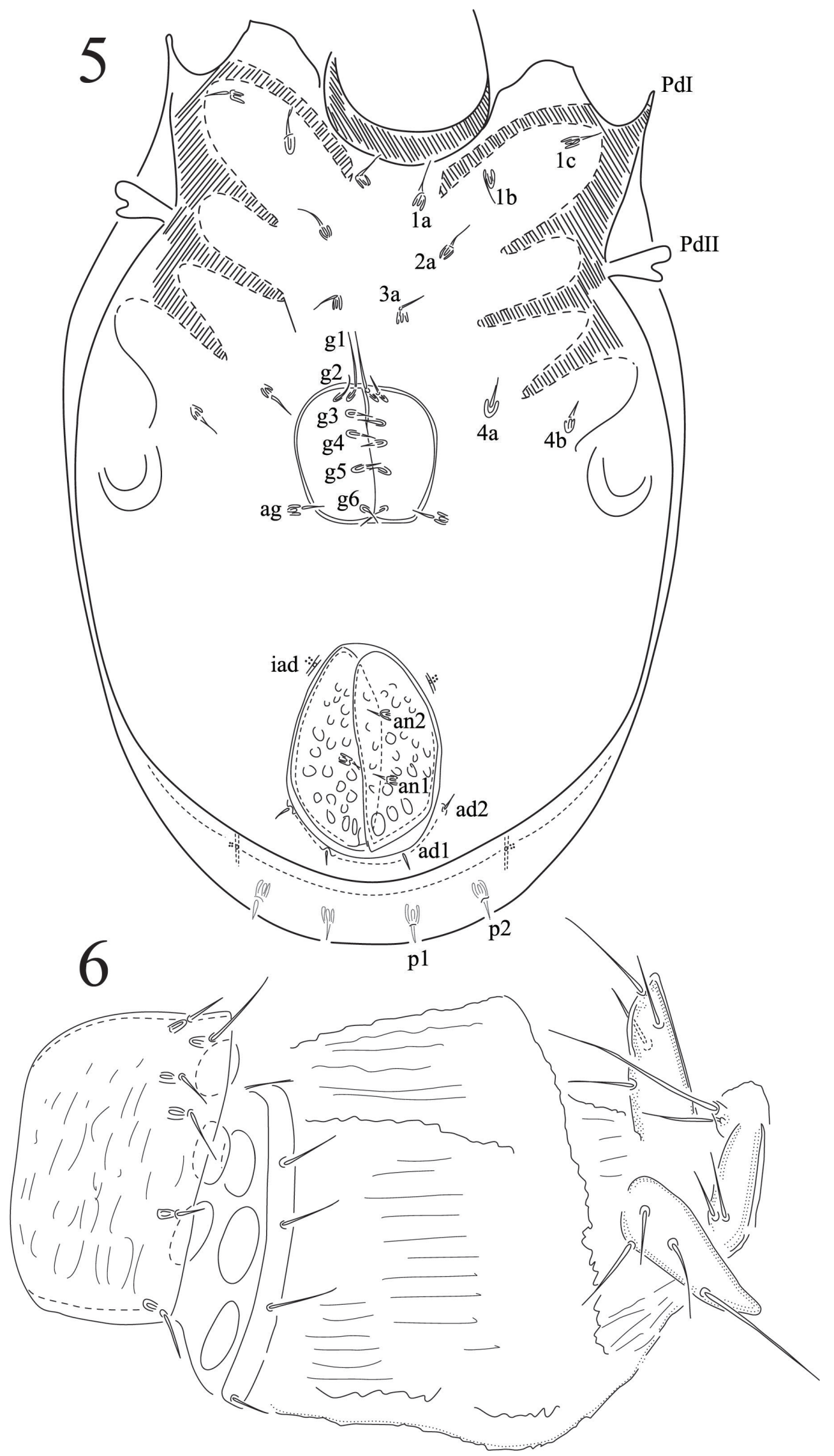

Figures 5-6. Scapheremaeus dirzoius sp. nov. 5, venter chaetotaxy; 6, genital plates and ovipositor. 


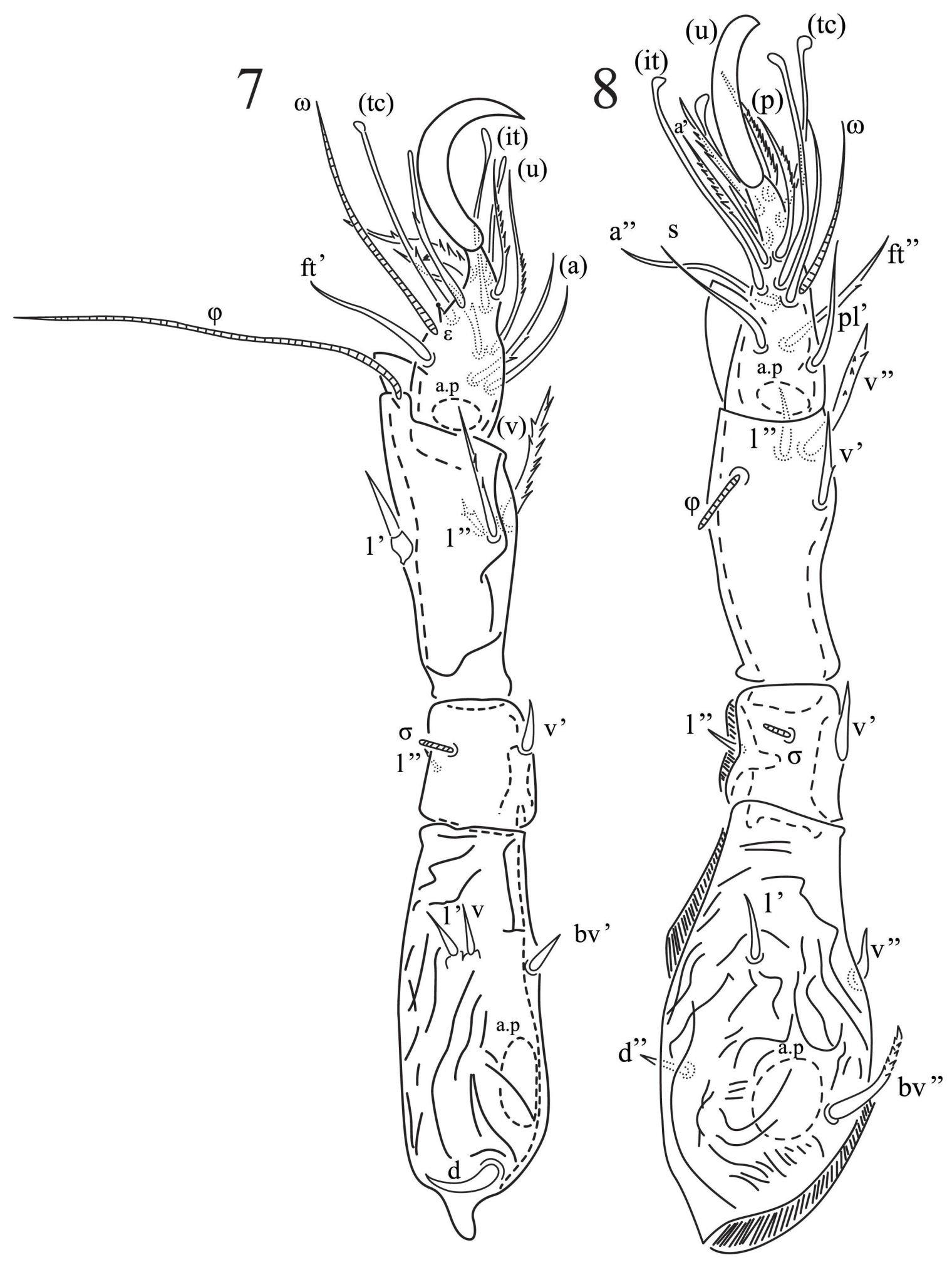

Figures 7-8. Scapheremaeus dirzoius sp. nov. 7, left leg I, antiaxial view; 8, left leg II, antiaxial view. 


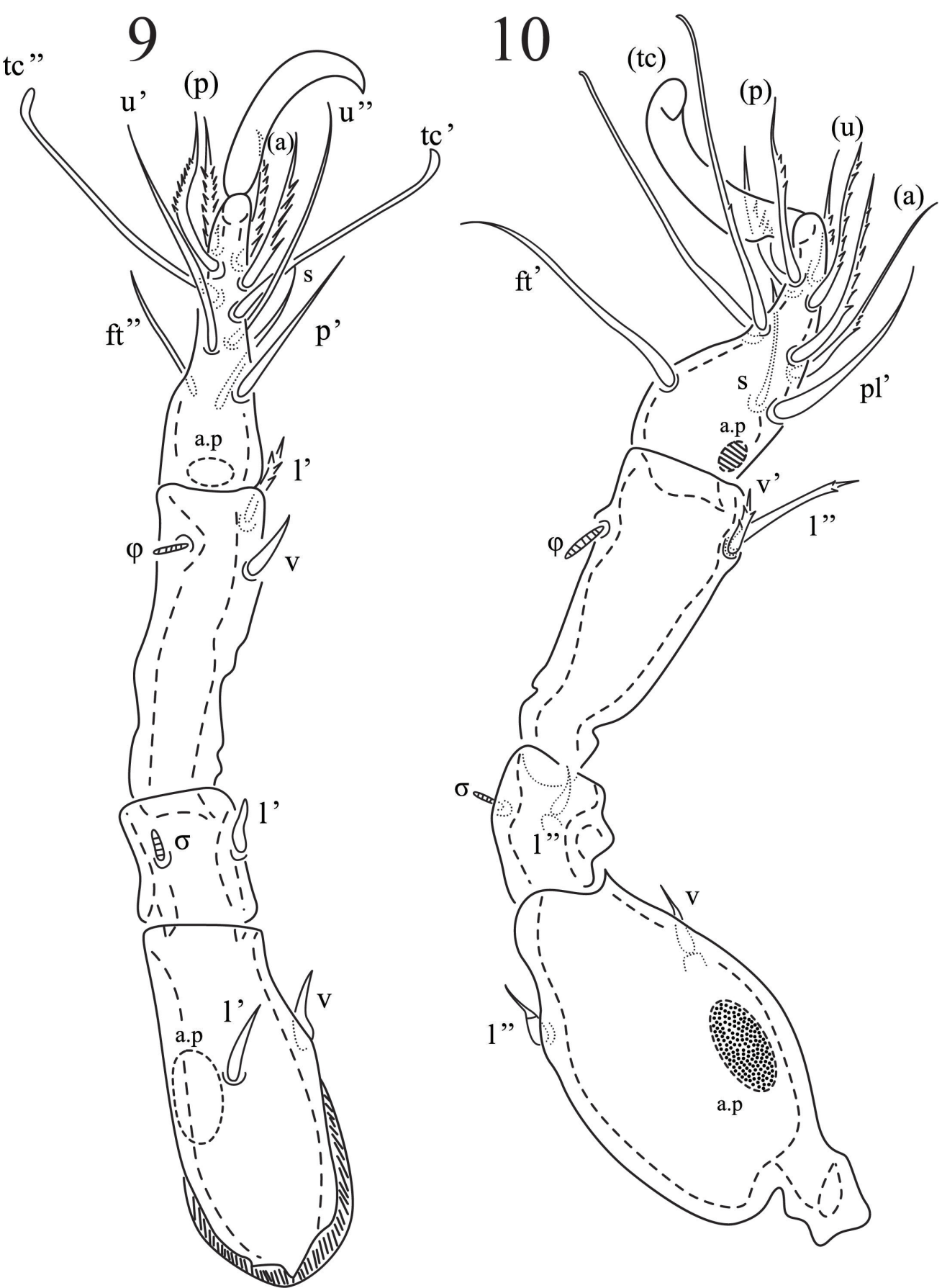

Figures 9-10. Scapheremaeus dirzoius sp. nov. 9, left leg III, antiaxial view; 10, right leg IV, paraxial view. 